\title{
PROSEDUR AUDIT LAPORAN KEUANGAN MASJID
}

\author{
${ }^{1 *}$ Sri Rahayu, ${ }^{2}$ Farida Titik K, ${ }^{3}$ Achmad Manshur Ali Suyanto, ${ }^{4}$ Elly Suryani, \\ ${ }^{5}$ Nurvita Trianasari \\ Universitas Telkom, Bandung, Jawa Barat, Indonesia \\ Email : "srirahayu@telkomuniversity.ac.id
}

Manuskrip: Desember -2021; Ditinjau: Januari -2022; Diterima: Januari -2022; Online: Januari-2022; Diterbitkan: Januari-2022

\begin{abstract}
ABSTRAK
Audit bertujuan untuk meyakinkan kembali bahwa laporan keuangan yang dimiliki suatu entitas telah disusun melalui prinsip dan standar akuntansi yang berlaku dalam hal ini termasuk pertanggungjawaban penyelenggaran penerimaan dan pengeluaran keuangan pada rumah ibadah yang merupakan entitas yang masuk dalam kategori entitas nonlaba. Dalam audit laporan keuangan akan dipastikan kembali bahwa suatu entitas telah melaporkan jumlah keuangan sesuai dengan keadaan sebenarnya pada tanggal pelaporan yang dicantumkan. Dari hasil pengabdian pada masyarakat sebelumnya telah dilakukan pendampingan penyusunan laporan keuangan untuk rumah ibadah dan tatacara Publikasi Laporan Keuangan Masjid melalui Website. Tahap selanjutnya adalah dengan adanya keinginan dan permintaan dari mitra sebagai bentuk pertanggungjawaban pengurus DKM kepada umat untuk memberikan keyakinan kesesuaian laporan keuangan yang disusun dengan standar akuntansi yang berlaku, maka pengurus masjid memerlukan opini dari pihak yang independent yaitu auditor. Pada program pengabdian ini merupakan program pengabdian lanjutan, pada pelaksanaannya diberikan pengetahuan dan pelatihan bagi para pengurus masjid / Dewan Kemakmuran Masjid untuk dapat mempersiapkan dalam menghadapi audit yang dilaksakanan sesuai dengan prosedur audit yang dilakukan oleh auditor sehingga opini audit diharapkan dapat diperoleh wajar tanpa pengecualian oleh masjid Nurul Masyriq ini. Namun yang paling sesuai setelah berkonsultasi dengan KAP maka yang digunakan adalah SJT 4400: perikatan untuk melakukan prosedur yang disepakati atas informasi keuangan, sehingga hasil akhir Laporan perikatan ini memberikan petunjuk secara jelas bahwa laporan keuangan ditujukan kepada pihak-pihak yang ditentukan yang memberikan manfaat.
\end{abstract}

\section{Kata Kunci: Masjid, Laporan Keuangan, Rumah Ibadah, Audit}

\section{PENDAHULUAN}

Salah satu alat bantu dalam melaksanakan fungsi utama manajemen adalah fungsi pengawasan dan pengendalian adalah aktivitas audit. Tujuan audit sendiri adalah untuk menyatakan pendapat tentang kewajiban, dalam semua hal yang material, posisi keuangan, hasil usaha, perubahan, ekuitas, dan arus kas sesuai dengan 
prinsip akuntansi yang berlaku umum di Indonesia. Audit adalah pemeriksaan yang dilakukan untuk secara kritis dan sistematis oleh pihak yang independen, laporan keuangan yang disusun oleh manajemen dan catatan akuntansi dan bukti pendukung, dalam rangka memberikan pendapat atas kewajaran laporan keuangan (Sukrisno Agoes 2017). Audit laporan keuangan bertujuan untuk menentukan apakah laporan keuangan secara keseluruhan informasi yang diuji telah disajikan sesuai dengan kriteria yang telah ditentukan. Pada umumnya kriteria yang telah ditetapkan tersebut adalah prinsip akuntansi yang berlaku umum yaitu Standar Akuntansi Keuangan (SAK) (Bayangkara, 2017)

Prosedur audit adalah metode yang digunakan auditor untuk memperoleh bukti audit. Bukti audit ini nantinya akan menjadi dasar bagi auditor dalam memberikan opini mereka atas laporan keuangan. Selain itu, prosedur audit dilakukan untuk menguji berbagai asersi audit yang terkait dengan kelas transaksi dan saldo akun yang berbeda.

Auditor perlu menerapkan berbagai jenis prosedur audit untuk memperoleh bukti audit yang akurat. Dalam hal ini, prosedur yang dilakukan auditor biasanya tergantung pada risiko yang dihadapi auditor. Auditor perlu menggunakan pertimbangan profesional mereka untuk merancang prosedur audit yang sesuai untuk merespons risiko yang dinilai. Selain itu, berbagai jenis prosedur audit biasanya didasarkan pada berbagai jenis bukti audit yang ingin diperoleh auditor.

Sampai dengan saat ini masih sangat sedikit sekali rumah-rumah ibadah yang telah memiliki laporan keuangan terlebih yang melakukan audit untuk laporan keuangannya sebagai akuntabilitas atau pertanggungjawaban pengurus kepada umat.

\section{Potensi / peluang pemberdayaan masyarakat sasar}

Yang menjadi masyarakat sasar kegiatan Pengabdian Kepada Masyarakat ini adalah pengurus DKM masjid di lingkungan RW (Rukun Warga). Hal ini ditentukan berdasarkan adanya permintaan dari pihak pengurus / DKM setelah adanya laporan keuangan sebagai pertanggungjawaban penyelenggaraan Masjid sebagai bentuk akuntabilitas dan transparansi, langkah selanjutnya adalah melakukan audit atas laporan keuangan. Salah satu kendalanya adalah minim literasi ketidakpahaman dalam hal persiapan dan menghadapi pelaksanaan audit yang dilakukan oleh auditor. Sampai dengan saat ini bentuk pertanggungjawaban sudah memiliki laporan keuangan yang merupakan hasil dari luaran program pengabdian kepada masyarakat sebelumnya (periode $1-2021$ ).

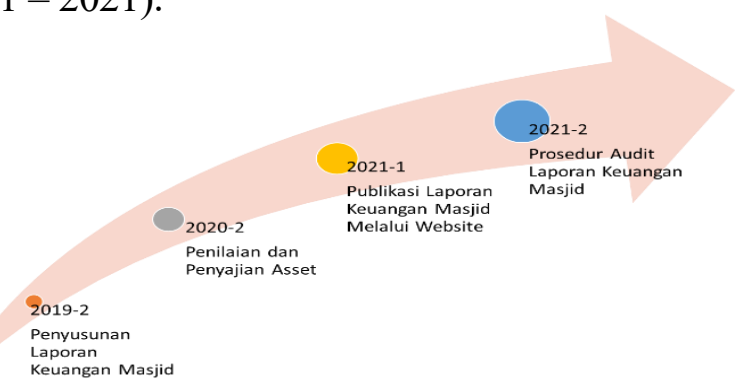

Gambar 1. Keberlanjutan program PKM 
Masjid Nurul Masyriq memiliki visi:

Menjadikan masjid nurul masyriq sebagai tempat nyaman, aman dan kekeluargaan bagi masyarakat muslim (khususnya ujungberung indah) dalam beribadah, beramal dan bermasyarakat

misi :

1. memakmurkan masjid dengan kegiatan da'wah dan ubuddiyah

2. menjadikan masjid sebagai tempat pembinaan umat muslim

3. menjadikan masjid sebagai rujukan pemahaman keislaman

4. menjadikan masjid tempat solusi kehidupan bermasyarakat dalam beragama islam Serta value: integritas, transparansi dan akuntabilitas

1. integritas : membentuk kepengurusan yang jujur dan berkomitmen kuat serta bertanggung jawab

2. Transparansi : menyajikan laporan keuangan secara berkala dan menganut prinsip keuangan yang terbuka

3. akuntabilitas : mempertanggung jawabkan program kerja atas "cost \& benefit" yang diperoleh

Masjid ini telah memiliki website dan informasi-informasi terkait kegiatan masjid dapat dikunjungi pada laman http://masjidnurulmasyriq.com/.
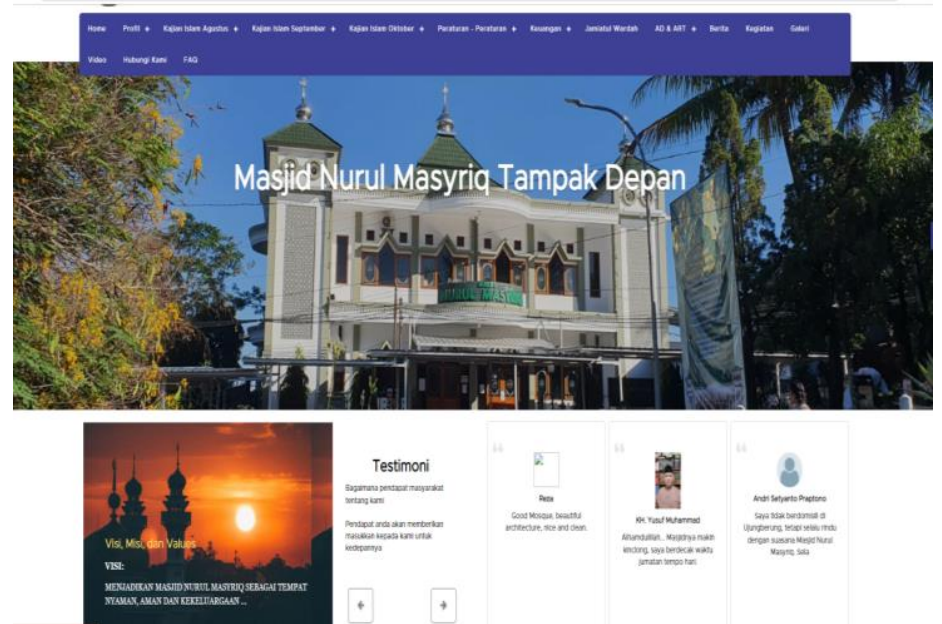

Gambar 2. Masjid Nurul Masyriq

Tim pengabdian kepada masyarakat Telkom University telah memberikan pendampingan dalam penyusunan laporan keuangan, Publikasi laporan keuangan masjid melalui website sebagai bentuk pertanggungjawaban. Pada kesempatan kali ini pengurus masjid di lingkungan RW 11 mengharapkan Kembali kelanjutan program pengabdian berupa upaya transparansi dan memperoleh opini melalui persiapan dalam menghadapi prosedur audit yang akan dilakukan oleh auditor guna memperoleh opini atas laporan keuangannya. 


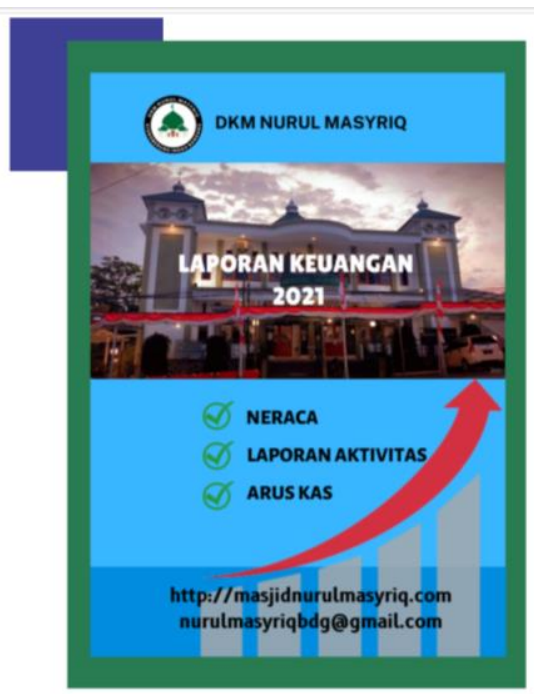

Gambar 3. Publikasi laporan keuangan masjid Nurul Masyriq pada website

\section{Solusi pengabdian masyarakat}

Tujuan diadakannya kegiatan pengabdian kepada masyarakat ini dengan tema pelatihan persiapan menghadapi prosedur audit laporan keuangan masjid di lingkungan RW 11 Cigending, Ujung Berung adalah sebagai berikut:

1. Pemeriksaan catatan atau dokumen

2. Pemeriksaan aset berwujud

3. Pengamatan Atau Observasi

4. Perhitungan ulang

5. Performa Ulang

6. Prosedur analitis

Adapun manfaat yang diharapkan dari kegiatan ini untuk para pengurus / Dewan Kemakmuran Masjid sebagai mitra adalah sebagai berikut:

1. Dapat mempersiapkan pemeriksaan catatan atau dokumen dengan proses pengumpulan bukti dengan memeriksa catatan atau dokumen, dengan cara menjamin catatan transaksi ke dokumen pendukung atau menelusuri dokumen pendukung ke catatan transaksi.

2. Dapat mempersiapkan pemeriksaan aset berwujud berupa pemeriksaan fisik aset berwujud seperti properti, dan peralatan. Jenis prosedur audit ini dapat memberikan bukti keberadaan aset berwujud dan sampai memeriksa dokumen hukum aset.

3. Dapat mempersiapkan observasi yang dilakukan auditor dengan melihat prosedur yang dilakukan oleh klien. Jenis prosedur audit ini memberikan bukti bahwa prosedur klien benar-benar terjadi pada saat auditor melakukan observasi.

4. Dapat mempersiapkan perhitungan ulang yaitu penghitungan ulang pekerjaan yang telah dilakukan klien untuk melihat apakah terdapat hasil yang berbeda antara pekerjaan auditor dan pekerjaan klien. Misalnya, auditor dapat melakukan 
penghitungan ulang atas penyusutan aset tetap untuk menguji asersi penilaian mereka.

5. Dapat mempersiapkan Re-performance dimana auditor secara independen melakukan prosedur pengendalian yang semula dilakukan sebagai bagian dari sistem pengendalian internal oleh klien. Jenis prosedur audit ini digunakan untuk menguji prosedur pengendalian klien.

Dapat mempersiapkan prosedur analitis yaitu mengevaluasi informasi keuangan melalui analisis kecenderungan, rasio atau hubungan antar data baik data keuangan maupun non keuangan.

\section{METODE PELAKSANAAN KEGIATAN}

Implementasi dari kegiatan pengabdian kepada masyarakat ini dengan tema prosedur audit laporan keuangan masjid di lingkungan RW 11 Cigending, Ujung Berung ini dilaksanakan satu hari (full day workshop). Lebih lanjut, detail pelaksanaan pelatihan adalah sebagai berikut :

Tabel 1. Pelaksanaan kegiatan PKM

\begin{tabular}{|c|c|c|c|}
\hline $\begin{array}{l}\text { Keterangan/Materi } \\
\text { Pelatihan }\end{array}$ & Tempat & Waktu & Pemateri \\
\hline Registrasi & $\begin{array}{l}\text { Masjid Nurul Masxxia } \\
\text { Cigending, Ujung } \\
\text { Berung }\end{array}$ & $07.30 \mathrm{sd} 08.00 \mathrm{WIB}$ & Panitia \\
\hline Pembukaan & $\begin{array}{l}\text { Masjid Nurul Masxria } \\
\text { Cigending, Ujung } \\
\text { Berung }\end{array}$ & $08.00 \mathrm{sd} 08.30 \mathrm{WIB}$ & $\begin{array}{l}\text { DKM Nurul } \\
\text { Massxia dan Ir. } \\
\text { Achmad Mansur } \\
\text { Ali Suyanto, MM. } \\
\text { DBA }\end{array}$ \\
\hline $\begin{array}{l}\text { Renaebalan dan tyiugan } \\
\text { audit }\end{array}$ & $\begin{array}{l}\text { Masjid Nurul Masxcia } \\
\text { Cigending, Ujung } \\
\text { Berung }\end{array}$ & 08.30 sd 10.00 WIB & $\begin{array}{l}\text { Dr. Farida Titik K., } \\
\text { SE., M.Si. }\end{array}$ \\
\hline Coffee Break & $\begin{array}{l}\text { Masjid Nurul Masyxia } \\
\text { Cigending. Ujung } \\
\text { Berung }\end{array}$ & 10.00 sd 10.15 WIB & Panitia \\
\hline Rrasedur Audit & $\begin{array}{l}\text { Masjid Nurul Masxxia } \\
\text { Cigending, Ujung } \\
\text { Berung }\end{array}$ & $10.15 \mathrm{sd} 12.00 \mathrm{WIB}$ & $\begin{array}{l}\text { Elly Surygai, SE., } \\
\text { MSS, Ak., CA., } \\
\text { CPA }\end{array}$ \\
\hline Ishoma & $\begin{array}{l}\text { Masjid Nurul Masxxia } \\
\text { Cigending, Ujung } \\
\text { Berung }\end{array}$ & $12.00 \mathrm{sd} 13.00 \mathrm{WIB}$ & Panitia \\
\hline Rersciaragn Dokumen Audit & $\begin{array}{l}\text { Masjid Nurul Massxigh } \\
\text { Cigending, Ujung } \\
\text { Berung }\end{array}$ & $13.00 \mathrm{sd} 14.00 \mathrm{WIB}$ & $\begin{array}{l}\text { Sri Rahayu, SE., } \\
\text { M.Ak., Ak., CA. }\end{array}$ \\
\hline $\begin{array}{l}\text { Penutupan } \\
\text { pembagian sertifikat }\end{array}$ & $\begin{array}{l}\text { Masjid Nurul Masxxia } \\
\text { Cigending, Ujung } \\
\text { Berung }\end{array}$ & 14.00 sd 14.30 WIB & $\begin{array}{l}\text { DKM } \quad \text { Nurul } \\
\text { Massxria dan Sri } \\
\text { Rahayu, SE., } \\
\text { M.Ak., Ak., CA. }\end{array}$ \\
\hline
\end{tabular}

\section{HASIL DAN PEMBAHASAN}

Tujuan diadakannya kegiatan pengabdian kepada masyarakat ini dengan tema pelatihan persiapan menghadapi prosedur audit laporan keuangan masjid di lingkungan RW 11 Cigending, Audit dilakukan berdasarkan kebutuhan entitas antara lain tergantung kepada:

a. Kewajiban dari regulator/pemerintah

b. (OJK, BEI, BI, Kementerian, Dirjen Pajak, dll)

c. Permintaan kreditur (Bank), tender

d. Permintaan pemegang saham, pemilik

e. Permintaan donatur, masyarakat

Pengurus DKM yang bersamaan dengan berakhirnya kepengurusan ingin memberikan pertanggungjawaban yang memiliki oponi dari pihak independent atas laporan keuangan yang dibuatnya, dimana penyusunan laporan keuangan masjid sesuai dengan Standar Akuntansi Keuangan (SAK) yaitu SAK untuk penyajian laporan keuangan Entitas berorientasi Non Laba (ISAK 35, 1 Jan 2020). 

meliputi:

Jika dilihat dari aktifitas kantor Akuntan Publik, maka jasa yang diberikan 1. Jasa Asuransi

2. Jasa Atestasi, yang terdiri dari
a. Audit of historical Financial Statetment (Jasa audit Laporan Keuangan)
b. Audit of IC over financial reporting
c. Review of historical Financial Statement (Jasa Review Laporan Keuangan)
d. Atestasi service on IT
e. Other assurance services (prosedur yang disepakati)

3. Jasa Non Asurans
a. Accounting and bookeeping services
b. Tax services
c. Management consulting services
Terkait dengan jasa yang sesuai dengan permintaan dari Dewan Kemakmuran Masjid ini maka dipilihlah prosedur yang sepakati sesuai dengan SJT 4400: perikatan untuk melakukan prosedur yang disepakati atas informasi keuangan, berikut gambaran keterkaitan jasa yang diberikan oleh KAP yaitu antara jasa assurance, attestation, dan nonassurance services (Arens. et.all, 2020).

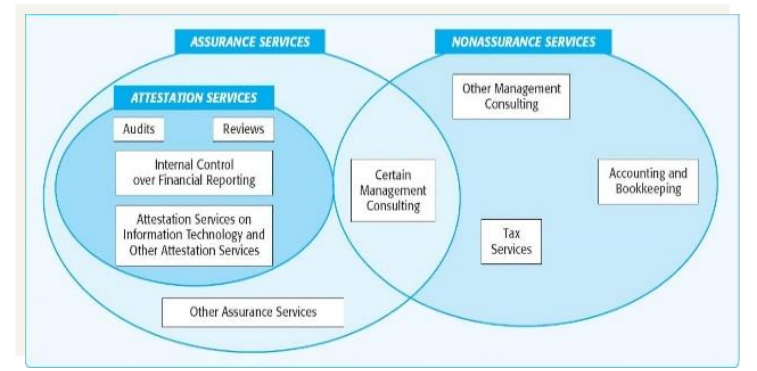

Gambar 4. Keterkaitan assurance, attestation, dan nonassurance services

Dalam melaksanakan audit sampai dengan memberikan opini, seorang auditor memerlukan bukti audit. Beberapa bukti audit diperoleh dengan melaksanakan prosedur audit untuk menguji catatan akuntansi, sebagai contoh melalui analisis dan penelaahan, pelaksanaan Kembali prosedur yang digunakan dalam penyusunan laporan keuangan, dan rekonsiliasi jenis dan aplikasi informasi sama yang berkaitan. Dengan melaksanakan prosedur audit, auditor dapat menentukan bahwa catatan akuntansi secara internal konsisten dan cocok dengan laporan keuangan (Standar audit, SA 500). Prosedur audit yang dapat digunakan sebagai prosedur penilaian resiko, pengujian pengendalian dan prosedur substantif, bergantung pada konteks yang diterapkan oleh auditor. Prosedur audit tersebut yaitu :
a) Inspeksi,
b) observasi,
c) konfirmasi eksternal,
d) penghitungan ulang,
e) pelaksanaan kembali, 
f) prosedur analitis,

g) permintaan keterangan.

Untuk mempersiapkan menghadapi prosedur audit yang dilakukan Kantor Akuntan Publik, maka persiapan-persiapan yang dilakukan oleh Dewan Kemakmuran Masjid antara lain menyiapkan dokumen Isi Laporan Keuangan standar yaitu:

1. Pernyataan Manajemen/Pengurus

2. Laporan Posisi Keuangan

3. Laporan Aktifitas

4. Catatan Atas Laporan Keuangan, berisi:

a. Informasi Umum Entitas (Akta Pendirian, Pengurus, Pemegang saham/donatur utama)

b. Kebijakan Akuntansi yang terkait Entitas

c. Rincian masing-masing akun Laporan Keuangan dan penjelasannya (pengungkapan/disclosure)

5. Lampiran Daftar Aset Tetap/Inventaris

6. Daftar Donatur (kalau banyak)

Dalam hal pemilihan Kantor Akuntan Publik, kami melalukan pendekatan dengan tujuan mendapatkan program CSR dari KAP tersebut sehingga pelaksanaan perikatan ini dapat bertujuan social.

\section{EVALUASI PELAKSANAAN PROGRAM}

Evaluasi dari pelaksanaan program ini adalah dengan memberikan kuesioner yang diisi oleh seluruh peserta dari masyarakat sasar. Kuesioner ini adalah kuesioner sesuai dengan format yang telah ditentukan oleh PPM Telkom University mewajibkan kepada setiap tim pengabdian untuk memberikan kuesioner kepada para peserta yang menilai tim pengabdian serta kepuasan terhadap pelaksanaan kegiatan. Adapun pertanyaannya kepuasan ini meliputi :

1) Program pengabdian masyarakat ini sudah sesuai dengan tujuan kegiatan itu sendiri,

2) Program pengabdian kepada masyarakat ini sudah sesuai dengan kebutuhan masyarakat sasarnya,

3) Waktu pelaksanaan program pengabdian masyarakat ini relatif telah mencukupi sesuai kebutuhan,

4) Dosen dan mahasiswa Universitas Telkom bersikap ramah, cepat dan tanggap membantu selama kegiatan,

5) Masyarakat setempat menerima dan mengharapkan program pengabdian masyarakat Universitas Telkom saat ini dan masa yang akan datang.

Hasil olahan kuesioner atas pertanyaan-pertanyaan kepuasan sebagai feedback yang diberikan oleh peserta terhadap tim dan pelaksanaan kegiatan pengabdian masyarakat diberikan pernyataan sangat tidak setuju, tidak setuju, setuju dan sangat setuju atas pernyataan - pernyataan yang diberikan. Hasil ini ditabulasi dan diolah sehingga dari rekapitulasi hasil feedback diperoleh nilai jumlah prosentase untuk masing-masing jawaban yang diberikan oleh seluruh 
peserta. Adapun rentangan penilaian untuk kepentingan evaluasi internal atas penyelenggaraan kegiatan yang telah ditentukan diberikan untuk jumlah pernyataan setuju dan sangat setuju.

Kurang $=($ jumlah Setuju + Sangat Setuju $<60 \%)$

Cukup $=(60 \% \leq$ jumlah Setuju + Sangat Setuju $<70 \%)$

Baik $=(70 \% \leq$ jumlah Setuju + Sangat Setuju $<80 \%)$

Sangat Baik $=$ (jumlah Setuju + Sangat Setuju $\geq 80 \%$ )

Gambaran hasil untuk jawaban setuju dan jawaban sangat setuju atas pelaksanaan kegiatan pengabdian masyarakat ini tersaji di tabel 2 dan menunjukan pada rentang "Sangat Baik" yaitu pada nilai $100 \%$.

Tabel 2. Hasil Tanggapan Masyarakat Sasar

\begin{tabular}{|l|c|c|c|c|}
\hline \multirow{2}{*}{ Penilaian Terhadap Kegiatan } & \multicolumn{5}{|c|}{ Jumlah Masing-masing Faktor yang } \\
\cline { 2 - 5 } & $\begin{array}{c}\text { Dipertimbangkan } \\
\text { Setuju }\end{array}$ & $\begin{array}{c}\text { Tidak } \\
\text { Setuju }\end{array}$ & Setuju & $\begin{array}{c}\text { Sangat } \\
\text { Setuju }\end{array}$ \\
\hline $\begin{array}{l}\text { 1. Kegiatan ini sudah sesuai dengan tujuan kegiatan itu } \\
\text { sendiri }\end{array}$ & 0 & 0 & 0 & 4 \\
\hline $\begin{array}{l}\text { 2. Kegiatan ini sudah sesuai dengan kebutuhan } \\
\text { masyarakat sasarnya }\end{array}$ & 0 & 0 & 0 & 4 \\
\hline $\begin{array}{l}\text { 3. Waktu pelaksanaan kegiatan ini relatif telah } \\
\text { mencukupi sesuai kebutuhan }\end{array}$ & 0 & 0 & 0 & 4 \\
\hline $\begin{array}{l}\text { 4. Dosen dan mahasiswa Universitas Telkom bersikap } \\
\text { ramah, cepat dan tanggap membantu selama kegiatan }\end{array}$ & 0 & 0 & 0 & 4 \\
\hline $\begin{array}{l}\text { 5. Masyarakat setempat menerima dan mengharapkan } \\
\text { kegiatan Universitas Telkom saat ini dan masa yang } \\
\text { akan datang }\end{array}$ & 0 & 0 & 0 & 4 \\
\hline Jumlah & 0 & 0 & 0 & 20 \\
\hline \% (jumlah masing-masing : total) & 0 & 0 & 0 & $100 \%$ \\
\hline Jumlah \% setuju + sangat setuju & \multicolumn{4}{|c|}{$100 \%$} \\
\hline
\end{tabular}

Selain dari kuesioner untuk mengisi pernyataan-pernyataan, terdapat masukan-masukan terbuka yang dituliskan oleh masyarakat sasar secara tertulis disampaikan kepada tim dan selanjutnya dirangkum dengan hasil antara lain:

1. Perlu diperluas cakupannya

2. Agar dikembangkan program ini untuk masyarakat luas (masjid-masjid lain)

3. Dapat diperluas informasi program ini untuk menjaga dan meningkatkan kepercayaan jamaah

4. Dapat dibuat suatu template bentuk laporan keuangan sehingga dapat dimanfaatkan untuk masjid-masjid kecil

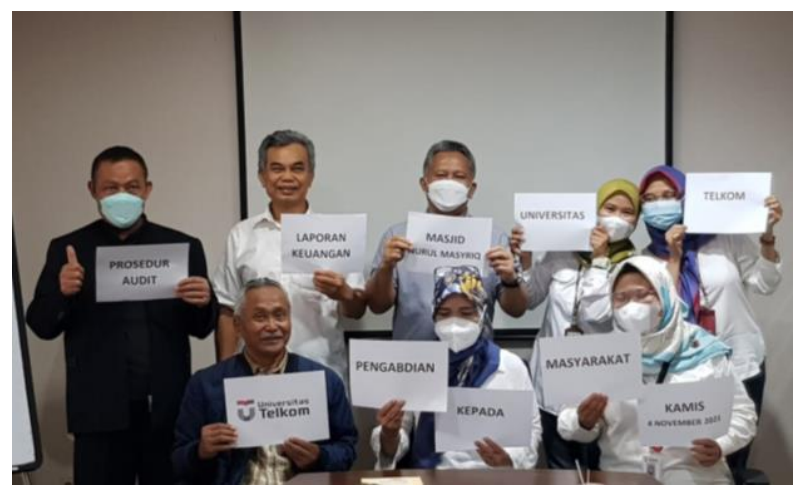

Gambar 5. Pelaksanaan PKM 


\section{KESIMPULAN}

Kegiatan pengabdian masyarakat dapat dilakukan secara berkelanjutan yang berupa pendampingan, kegiatan ini tentunya diawali dari respon kebutuhan mitra sasar. Dari tahap pengenalan laporan keuangan sampai dengan persiapan menghadapi prosedur audit yang akan dilakukan oleh auditor. Hasil dari kegiatan ini dapat langsung dirasakan manfaatnya oleh masyarakat dilihat dari kuesioner dan masukan yang diberikan. Kegiatan ini sangat penting untuk dilakukan dengan tujuan untuk mengaplikasikan ilmu dan membantu pihak masyarakat sasar dalam memecahkan masalah untuk terkait kebutuhan transparansi dari laporan keuangan dan memberikan keyakinan bahwa laporan keuangan tersebut sesuai dengan standar yang berlaku.

\section{UCAPAN TERIMA KASIH}

Atas kegiatan pengabdian kepada masyarakat ini tim penulis sampaikan banyak terimakasih kepada Universitas Telkom atas bantuan dan dukungannya, DKM Masjid Nurul Masyriq atas semangat dan antusisnya mengikuti program ini secara berkelanjutan, tim PKM dari persiapan, pelaksaaan, hingga terbitnya tulisan ini. Semoga kegiatan Pengabdian Masyarakat ini dapat berjalan dalam jangka panjang, untuk mendukung pelaksanaan kegiatan Tridharma Perguruan Tinggi yang memberikan dampak baik bagi masyarakat

\section{DAFTAR PUSTAKA}

Agoes, Sukrisno. 2017. Auditing: Petunjuk Praktis Pemeriksaan Akuntan oleh Kantor Akuntan Publik. Jakarta: Salemba Empat

Arens,Elder,Beasley, Hogan, Auditing and Assurance Services, 17th edition, 2020 Bayangkara, Audit Manajemen: Prosedur dan Implementasi, 2017, Salemba empat Hayes, Wallage, Gortemaker, Principles of Auditing, an Introduction to International Standard on Auditing,3rd edition, , 2014

Kode Etik Profesi Akuntan Publik, Institut Akuntan Publik Indonesia

Standar Akuntansi Keuangan (SAK), Ikatan Akuntan Indonesia

Standar Profesional Akuntan Publik (SPAP), Institut Akuntan Publik Indonesia, (terbaru)

Theodorus M. Tuanakota, Audit Berbasis ISA, 2013

UU, PP, POJK dan PMK tentang Akuntan Publik 